\title{
From climate-smart agriculture to climate-smart landscapes
}

\author{
Sara J Scherr ${ }^{*}$, Seth Shames and Rachel Friedman
}

\begin{abstract}
Background: For agricultural systems to achieve climate-smart objectives, including improved food security and rural livelihoods as well as climate change adaptation and mitigation, they often need to be take a landscape approach; they must become 'climate-smart landscapes'. Climate-smart landscapes operate on the principles of integrated landscape management, while explicitly incorporating adaptation and mitigation into their management objectives.

Results: An assessment of climate change dynamics related to agriculture suggests that three key features characterize a climate-smart landscape: climate-smart practices at the field and farm scale; diversity of land use across the landscape to provide resilience; and management of land use interactions at landscape scale to achieve social, economic and ecological impacts. To implement climate-smart agricultural landscapes with these features (that is, to successfully promote and sustain them over time, in the context of dynamic economic, social, ecological and climate conditions) requires several institutional mechanisms: multi-stakeholder planning, supportive landscape governance and resource tenure, spatially-targeted investment in the landscape that supports climate-smart objectives, and tracking change to determine if social and climate goals are being met at different scales. Examples of climate-smart landscape initiatives in Madagascar's Highlands, the African Sahel and Australian Wet Tropics illustrate the application of these elements in contrasting contexts.

Conclusions: To achieve climate-smart landscape initiatives widely and at scale will require strengthened technical capacities, institutions and political support for multi-stakeholder planning, governance, spatial targeting of investments and multi-objective impact monitoring.
\end{abstract}

Keywords: Climate change adaptation, Climate change mitigation, Climate-smart agriculture, Integrated landscape approach

\section{Introduction: climate-smart and landscape approaches}

The links between agriculture and climate change have been well documented (major reviews cited in [1]), and agriculture must play a major role in global efforts to address both adaptation and mitigation. But including climate change objectives requires new approaches to agricultural development that more explicitly address ecosystem health and resilience, and action and impacts that can be realized at scale. This introduction briefly summarizes those agriculture-climate change links and the implications for 'climate-smart' agriculture, and then taps the experience of integrated landscape initiatives to

* Correspondence: sscherr@ecoagriculture.org

EcoAgriculture Partners, 1100 17th St., NW, Suite 600, Washington, DC 20036, USA

\section{() Biomed Central}

propose a 'climate-smart landscape' approach that will be elaborated in the rest of the article.

\section{Climate change and agriculture}

Climate change will influence crop distribution and production and increase risks associated with farming. Crop yields have already experienced negative impacts, underlining the necessity of taking adaptive measures $[2,3]$. While a few areas, mainly in temperate latitudes, may experience improved conditions for production, globally, climate change is expected to reduce cereal production by $1 \%$ to $7 \%$ by 2060 [4]. There is also substantial variation in likely impacts by crop, irrigated versus rain-fed agriculture, and geographic region [3]. At least $22 \%$ of the cultivated area under the world's most important crops is projected to experience negative impacts from 
climate change by 2050 , with as much as $56 \%$ of the land area in sub-Saharan Africa [5]. Impacts may be relatively small up to 2050, but are expected to become progressively worse in the second half of the century [6].

Beyond the changes in crop production and yield associated with climate change, there are other areas that require adaptation efforts. Climate-induced water scarcity from changes in temporal and spatial distribution of rainfall could lead to increased competition within the agriculture sector and with other sectors [7]. Moreover, addressing this and other challenges would require modifying physical infrastructure, such as irrigation systems and altering the design and location of storage facilities $[7,8]$. Increased risk from flood and droughts, and shifting fire regimes all pose additional threats to agricultural production $[9,10]$. Uncertainties in climate regimes could also influence how farmers make decisions, and whether they invest in necessary inputs and resources for their land.

Meanwhile, roughly $30 \%$ of the world's greenhouse gas emissions come from land use [11]. An estimated 18\% come from land use change (primarily deforestation) and another $10 \%$ to $12 \%$ from crop production (soil erosion and tillage, nitrogen fertilizer, and paddy rice cultivation). Livestock production (from animal digestion, feed production, manure management, and forest cover loss) contributes about $14.5 \%$ of global greenhouse gas emissions and nearly half of the agriculture sector's emissions, from enteric fermentation and land clearing [11].

Land use represents the largest climate mitigation potential in many countries. Indeed, only land-based carbon sequestration efforts currently offer the possibility of large-scale removal of greenhouse gases (GHG) from the atmosphere, through photosynthesis and carbon sequestration in soils and perennial plants. Agricultural soil carbon accounts for $89 \%$ of the technical sequestration potential, representing an estimated potential of between 5.5 and 6 gigatons of $\mathrm{CO}_{2}$ emissions per year, which roughly equals agriculture's total yearly contribution to global emissions [11]. Significant sources of emissions reductions include improved feed systems and manure management, more efficient fertilizer use, reducing deforestation and wetland conversion, and restoring degraded lands [11]. Changes in land management and land use may also moderate local and regional climate through changes in albedo, evapotranspiration, soil moisture and temperature [12]. Moreover, within agriculture, many adaptation measures have significant mitigation cobenefits. For example, increasing soil organic matter improves adaptive capacity by increasing soil water holding capacity and soil fertility, while also sequestering carbon [9].

As the links between climate change and agriculture have become better understood in the scientific community, international and national public policy efforts to support agricultural adaptation and mitigation have intensified. Support for bringing agriculture more centrally into climate change negotiations has been steadily strengthening since Copenhagen's 15th Conference of the Parties (COP 15). The first Agriculture and Rural Development Day Agriculture officially found a place on the agenda of the 2012 Subsidiary Body for Scientific and Technological Advice (SBSTA) meeting, and a parallel high-level international process addressing Agriculture, Food Security and Climate Change launching in 2010 in The Hague [13,14]. Moreover, in these processes there has been increasing emphasis on adaptation, with the development of National Adaptation Programme of Action (NAPA) initiatives and the Adaptation Fund, and more specifically on agriculture in developing countries.

\section{Climate-smart agriculture}

As research and policy links between climate change and agriculture have advanced, 'climate-smart agriculture' has emerged as a framework to capture the concept that agricultural systems can be developed and implemented to simultaneously improve food security and rural livelihoods, facilitate climate change adaptation and provide mitigation benefits. Since it emerged in 2010, the development of this idea and use of the term itself, has been led by international institutions, particularly the United Nations Food and Agriculture Organization (FAO) and the World Bank [15,16]. The Consultative Group on International Agricultural Research (CGIAR) has provided leadership to the international research community as the idea has matured $[3,17,18]$.

While newly framed as a concept for the climate change and agricultural development communities, climate-smart agriculture includes many of the field-based and farmbased sustainable agricultural land management practices already in the literature and in wide use, such as conservation tillage, agroforestry, residue management, and others $[5,13,15,16,19,20]$. Most of the focus of climate-smart agriculture has been on the implementation of these field and farm practices, and the ways that they can be improved in the context of a changing climate. Many others are engaged in the discourse on agricultural practices for climate change adaptation and mitigation, but without using the climate-smart terminology [6,11,21-23].

However, climate-smart agriculture requires actions beyond the farm scale. One element of FAO's definition is 'adopting an ecosystem approach, working at landscape scale and ensuring intersectoral coordination and cooperation' [15]. In the World Bank's version, climatesmart agriculture includes integrated planning of land, agriculture, fisheries, and water at multiple scales (local, watershed, regional)' [16]. Yet while landscapes are clearly considered a key component of the climate-smart 
conceptual framework, there have been few efforts to elucidate the mechanisms to implement climate-smart landscapes.

\section{Integrated landscape management}

Parallel to development of the climate-smart discourse has been the emergence of integrated landscape management as an organizing framework for action and policy within the agricultural development and conservation communities [24,25]. Integrated landscape management approaches work deliberately to support food production, ecosystem conservation, and rural livelihoods across entire landscapes. These are known under various terms including ecoagriculture, landscape restoration, territorial development, model forests, satoyama, integrated watershed management, agroforestry landscapes, and the ecosystem approach to managing agricultural systems, among many others. While differing somewhat in focus, all of these landscape approaches have five elements in common (see Table 1).

\section{Climate-smart agricultural landscapes}

The integrated landscape approach offers a strategy to achieve climate-smart agriculture objectives at scale and in all its dimensions. Through climate-smart agricultural landscapes, important synergies for agricultural production, climate adaptation and mitigation, as well as other livelihood and environmental objectives, can be generated through coordinated action at farm and landscape scales (see Figure 1).

The next section describes the key features of integrated landscape management as they relate to climate-smart objectives. The following section discusses key institutional mechanisms that are required to implement climatesmart landscapes. Case studies are then presented that demonstrate how landscape initiatives with diverse entry

\section{Table 1 Elements of integrated agricultural landscape management [26]}

1) Landscape interventions are designed to achieve multiple objectives, including human well-being, food and fiber production, climate change mitigation, and conservation of biodiversity and ecosystem services

2) Ecological, social and economic interactions among different parts of the landscape are managed to seek positive synergies among interests and actors or reduce negative trade offs

3) The key role of local communities and households as both producers and land stewards is acknowledged

4) A long-term perspective is taken for sustainable development, adapting strategies as need to address dynamic social and economic changes

5) Participatory processes of social learning and multi-stakeholder negotiation are institutionalized, including efforts to involve all parts of the community and ensure that the livelihoods of the most vulnerable people and groups are protected or enhanced [20] points (food security, adaptation, mitigation, watershed management, biological corridors, and so on) can contribute to meeting climate-smart objectives. The paper concludes with recommendations to support the development and implementation of landscape approaches for climatesmart agriculture.

\section{Key features of climate-smart agricultural landscapes}

Climate-smart agricultural landscapes operate on the principles of integrated landscape management, while explicitly integrating adaptation and mitigation into their management objectives.

An assessment of climate change dynamics related to agriculture suggests three key features characterize a climate-smart landscape: climate-smart practices at the field and farm scale; diversity of land use across the landscape; and management of land use interactions at landscape scale.

\section{Climate-smart practices at field and farm scale}

Climate-smart landscapes are comprised of a variety of field and farm practices, in different land and tenure types, that support both adaptation and mitigation objectives. These practices include soil, water and nutrient management along with agroforestry, livestock, husbandry, and forest and grassland management techniques [15,23,28-30].

Building soil organic matter is critical for increasing agricultural resilience to climate change. Minimal tillage and using cover crops and crop residues enhance the organic matter stored in soil, while also supporting biological processes and nutrient and hydrological cycling [19,31]. Farming with perennials that develop root and woody biomass can substitute for an annual tillage regime, providing year-round ground cover and retaining organic matter and water in soil. Transition from annual crops to fields of perennials has been estimated to increase soil carbon by $50 \%$ to $100 \%$ [32]. Soil is the third largest carbon pool on earth's surface, and so maintaining and enhancing this stock is essential for mitigation efforts [23].

More efficient management of water, a resource threatened by climate change, is also critical for reaching the adaptation and livelihood goals of climate-smart agriculture. Best practices for irrigation, water-harvesting technology, and terrace or contour farming systems can contribute to improved water-use efficiency and conservation [19]. Incorporating the shifts in hydrologic regimes and water availability due to climate change into the design and management of water systems will enhance adaptation [9]. Particularly in semi-arid and arid regions, where water resources are already a concern, investment in irrigation increases production, reduces 


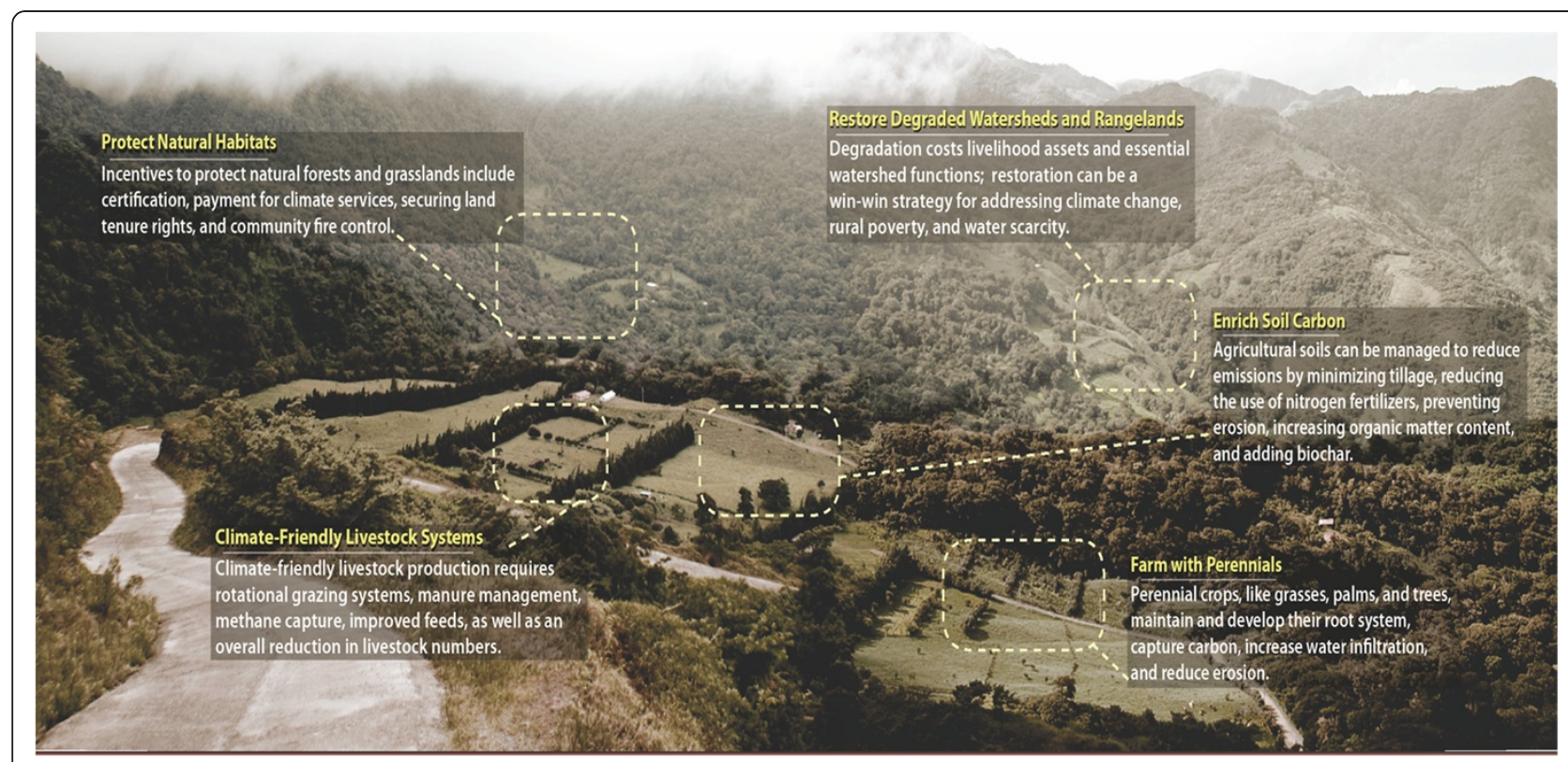

Figure 1 Components of a climate-smart landscape [27].

variability, and may spur additional investment in agriculture [29]. Improved design, construction processes and water delivery mechanisms can greatly reduce the very high GHG emissions associated with conventional irrigation systems.

Employing integrated nutrient management principles, such as green manures, planting nitrogen-fixing crops, and incorporating livestock manures into the soil, decreases the amount of nitrogen lost to runoff and emissions of nitrous oxide. Applying these management principles can serve adaptation needs by improving soil quality, while also decreasing farmers' costs and dependence on outside inputs. Organic farming and use of nonsynthetic inputs, can increase the amount of carbon and nitrogen retained in the soil by $15 \%$ to $28 \%$ and $8 \%$ to $15 \%$ respectively, simultaneously reducing the costs of inputs for farmers (see [19]).

Agroforestry, the use of live fences or intermingled crops and trees, is another strategy to achieve climatesmart objectives. Agroforestry and tree crops increase resilience of local communities by providing a diversity of fruits, nuts, medicines, fuel, timber, nitrogen-fixation services, fodder, and habitat. Furthermore, these economically useful trees and shrubs can reduce soil erosion and maintain higher levels of biomass than annually tilled crops (through extended growth periods and root systems), also storing more carbon [19].

Livestock management strategies are particularly critical for climate-smart agriculture. Improved pasture and grassland management, including rotational grazing, regenerate vegetation and restore degraded land which will be critical for climate change resilience. They also contribute to mitigation through carbon sequestration in deep-rooted vegetation and soils. For better manure management, converting manure to biogas provides the added benefits of an alternative energy source with fewer negative health impacts from cooking, heating, and lighting. Improved feed mixes and nutritional supplements can decrease methane emissions; however this is more feasible at larger scales of operation.

\section{Diversity of land use across the landscape}

A second feature of climate-smart landscapes is a high level of diversity. This includes land cover, land use, and species and varietal diversity of plants and animals. Diversity has several climate mitigation and adaptation functions: (1) to reduce risks of production and livelihood losses from erratic and harsh climatic conditions; (2) to utilize areas of the landscape strategically as emergency food, feed, fuel, and income reserves; and (3) to sustain minimally disturbed habitats within the landscape mosaic that also serve as carbon stocks.

\section{Reduce risk}

Diversity of land uses and species can reduce ecological risks associated with homogeneous crop cover, in terms of pests and diseases and vulnerability to unexpected weather conditions. Improving genetic diversity on farms, by increasing the number of different crops grown or the number of varieties of the same crops, also provides important climate adaptation and risk management benefits [33,34]. Crop genetic diversity improves the chances that some varieties will be suited to shifts in temperature, precipitation, and salinity regimes caused by climate change 
[35]. Moreover, having a portfolio of diverse food and income sources, from crops, livestock, trees, and noncultivated lands can cushion households and communities from climatic (and other) shocks [36,37].

\section{Provide strategic food and feed reserves}

Livelihood resilience of households and communities can also be enhanced through access to diverse sources of food, feed and employment during episodes of adverse climatic conditions. Wild plant species in farms, forests, savannahs and wetlands contribute significantly to the diets of many of the poor in developing countries, and these food sources, particularly the 'famine foods' such as wild greens, tree fruits, and roots, play an important role in supplementing diets during periods of climateinduced scarcity [38]. Species commonly used as food and feed reserves are hardier, have better (or in situ) storage characteristics, or lower demand for purchased inputs. Communities and local authorities can allocate lands for community and local district grazing reserves. Bush meat found in forests and fish from freshwater and coastal resources can be important sources of protein when climate disrupts agricultural systems.

\section{Sustain perennial habitat as carbon stocks}

The dominant farming systems today involve annual plant species. Maintaining other types of land cover throughout the landscape, such as perennial grasslands, woodlands, forests, or wetlands improves ecological resilience in terms of watershed functions and habitat for wildlife important for local livelihoods, tourism or biodiversity conservation. Maintenance or expansion of land area in these types of perennial systems is also one of the most effective ways to sequester carbon and reduce emissions from the landscapes [23].

\section{Management of land use interactions at landscape scale} The third important feature of climate-smart landscapes is management of land use interactions to enhance adaptation and mitigation. Stakeholders and planners must identify, negotiate and manage the impacts of different land uses and management on other land uses and users in the landscape. Active monitoring and management can reduce conflicts and generate synergies that help sustain stakeholder engagement in landscape management. The main benefits of this focus on landscape interactions are: (1) to enhance field-level benefits of climate-smart practices, (2) to secure ecosystem functions, and (3) to enhance the effectiveness of climate mitigation efforts.

\section{Enhance field-level benefits of climate-smart practices}

Intentional planning of the spatial arrangements of landscape elements can enhance field-level results [39].
Agricultural productivity is impacted by the land uses surrounding farms, where field margins, riparian buffers, and forest edges can harbor pest predators or beneficial insects [40]. For example, forest fragments adjacent to agricultural land uses increase and stabilize pollination services [41]. Agricultural nutrients and sediment can be managed to protect downstream fisheries, while upstream crop, livestock and forest production can be managed to improve the timing and flow of water for irrigation downstream. Methane from livestock wastes may be used to replace fossil fuels in local agroprocessing facilities.

\section{Secure ecosystem functions}

Natural and semi-natural habitats, such as riparian areas, woodlands and wetlands, can be sited and managed to provide ecological connectivity for water and nutrient flows, and improve habitat conditions for wild plant and animal species and beneficial microorganisms. As climate change intensifies, connectivity of wildlife habitats and hydrological resources will become increasingly important as an adaptation strategy [37,42]. Agricultural production practices need to support, rather than block, this connectivity. Large-scale rainwater harvesting can be designed to provide water for domestic household and environmental uses, as well as for irrigation. Animal and human disease control requires effective agricultural waste and water management across the watershed.

\section{Enhance effectiveness of mitigation efforts}

In addition to its importance for climate change resilience, managing land use dynamics across the landscape is critical for terrestrial mitigation efforts. Perhaps the land use interaction of most prominent concern in the climate community is that between agriculture and forests within the context of efforts to develop Reduced Emissions from Deforestation and Degradation (REDD) programs. Strategies for climate change mitigation and adaptation that seek to sustain forest cover inherently require participation of farmers and other stakeholders in agricultural systems. Specific on-farm agricultural practices sequester relatively small quantities of GHG compared to forest conservation. However, when agriculture and forest development are linked together as part of an integrated landscape livelihood strategy that highlights food security, adaptation, livelihood and other environmental objectives, overall deforestation and GHG emissions can be reduced more effectively and sustainably [27].

\section{Implementing climate-smart agricultural landscapes}

To implement climate-smart agricultural landscapes with the features described above (that is, to successfully 
promote and sustain them over time, in the context of dynamic economic, social, ecological and climate conditions) requires at least four institutional mechanisms: multi-stakeholder planning, supportive landscape governance and resource tenure, spatially-targeted investment in the landscape that supports climate-smart objectives, and tracking the multiple dimensions of change to determine if social, economic, ecosystem and climate goals are being met at different scales.

\section{Multi-stakeholder planning}

A foundational principle of the landscape approach is that all relevant stakeholders are involved in planning processes to negotiate priorities, recognizing legitimate local, regional, national, and business interests. These processes can provide the opportunity for landscape planning, program implementation and progress monitoring for climate-smart objectives, as well as others. Additionally, a multi-stakeholder process serves as a means to develop partnerships, consolidate resources, share knowledge, build coalitions, and pool investments.

Multiple sectors, including water, agriculture, livestock, energy, and lands, will need to be involved in climate-smart landscape planning, and stakeholders from environmental finance, planning authorities, producer groups, civil society business, and private investors must be engaged [43]. These planning processes should be informed by rigorous, multidisciplinary climate risk and vulnerability assessments tailored to specific landscapes and addressing scientific, economic, and social considerations $[44,45]$.

As rainfall and temperatures are modified by climate change, the geographic conditions of production systems and protected areas will shift, often requiring institutional responses, such as new zoning, protected area boundaries, or markets shifting to new suppliers. Such changes can be facilitated by landscape planning processes $[36,46]$.

Cross-border platforms, such as the Comprehensive Africa Agriculture Development Program (CAADP) [47] and territorial development initiatives, can also aid in policy and program coordination to support climatesmart landscapes. Regional development programs can be utilized as dialogue platforms to coordinate small local projects. Farmer groups and local civil society organizations must fully participate in these processes, but may require capacity building and support to do so.

\section{Supportive landscape governance and resource tenure}

Decentralized governance is key to an enabling policy environment for climate-smart landscapes, so that local stakeholders determine key planning decisions and can incorporate local needs and priorities. Control of resources by local institutions and organizations increases the scope for improved landscape management and benefits for local actors $[29,43]$.

Secure systems of land and resource ownership, use and access rights and property rights are also critical for successful, long-term management. Secure tenure allows land managers to look towards a future where they can build profitable, climate-resilient systems [15]. Insecure property rights pose a barrier to adoption of climatesmart practices, as there is little incentive to invest time and money to transition management practices. However, in some circumstances, it may be necessary to shift tenure rules and rights in response to climate change impacts on natural resource conditions $[27,43]$.

\section{Financing for integrated landscape investments}

Public and private investment programs must be structured in a way that supports climate-smart landscapes. Such investment may be financed through climate programs, or climate criteria may be incorporated into sectoral funding sources or through a special window for intersectoral funding of activities that have climate cobenefits.

Agricultural investments typically target production and supply chains for particular products based on growing conditions, institutional context, and market infrastructure. Spatial or ecosystem criteria can be added to develop marketing strategies that target specific ecological niches and social groups in a landscape [43].

Climate-smart elements can be incorporated into agroindustrial investment programs (for example, the Agricultural Green Growth strategy being developed in the Southern Agricultural Growth Corridor of Tanzania). Spatially targeted investments in agriculture can be linked to payment for ecosystem services (PES) schemes or ecocertification systems for agricultural products that further incentivize ecological management and climate resilience. Where investments are independently made by businesses, landholders or public agencies, there may be a role for landscape stakeholder forums to negotiate landscape tradeoffs and encourage potential synergies [43].

\section{Tracking multiple dimensions of change}

For stakeholders to invest in climate-smart landscapes, they must understand and be able to communicate the multiple benefits that these produce including yield improvements, food and energy security, adaptation, mitigation, human health, biodiversity conservation and other ecosystems services. Thus climate-smart landscape initiatives should monitor not only climate indicators (e.g. carbon sequestration, greenhouse gas emissions reductions), but the whole suite of objectives, as well as the effectiveness of key institutions for achieving current 
and future results [48]. More work is needed to develop indicators and measure the impacts of adaptation activities, particularly at the landscape scale. For example, the Adaptation Monitoring and Assessment Tool (AMAT) is being used to assess the efficacy of the LeastDeveloped Country Fund (LDCF) and Special Climate Change Fund (SCCF) in supporting adaptation to climate change [49]. Indicators to measure adaptation must be specific to socioeconomic, environmental, and climatic contexts under which adaptive measures are implemented [50]. More cost-effective approaches to estimating GHG emissions at landscape scale are also being developed and incorporated into more holistic monitoring systems [51]. These tracking efforts will help to devise more effective models for developing and managing climate-smart landscapes.

\section{Climate-smart landscape approaches: case examples}

Hundreds of integrated agricultural landscape initiatives have been documented worldwide: multi-stakeholder efforts spurred by leadership from local and national governments, NGOs, indigenous peoples' and farmer organizations, private resource-based companies and others [24]. Until recently, few focused explicitly on climate change adaptation and mitigation. But these integrated landscape models are now providing a variety of templates for building climate-smart agricultural landscapes. Similarly, though climate change adaptation and mitigation are the standard motivations for climate-smart agricultural initiatives, other goals of land rehabilitation, watershed management, food security, and biodiversity conservation are increasingly incorporated, with the aim of developing multifunctional landscapes.

For example, in a pilot project for climate resilience (PPCR) in Bangladesh adaptation needs are motivating climate-smart agriculture on a landscape and national scale [52]. Climate-smart water management initiatives include the Inner Niger Delta in Mali [53] and the use of zai planting pits in western Africa [19]. The Kagera Transboundary Agroecosystem Management Programme (TAMP) addresses land degradation in ways aligned with climate goals [15], as do several TerrAfrica programs on sustainable land management and climate change in Africa. Mitigation-oriented climate-smart agricultural projects at landscape scale include the Three Rivers Project in Qinghai province of northern China [15] and the Ankeniheny-Zahamena Corridor in Madagascar [54]. Climate-smart landscapes are being promoted by international organizations such as Environmental Defense Fund (in India and Vietnam) and Conservation International (REDD + agriculture and biodiversity conservation in diverse parts of the world). REDD + programs to slow deforestation are moving rapidly to embrace a landscape approach with explicit focus on agricultural land use and dynamics.

Most of these are in very early stages of implementation, so that rigorous documentation of impacts and cost effectiveness is not yet available. But it is instructive to examine how the principles and institutional mechanisms described above are being applied. These are summarized below (see Table 2) for three recently established landscape initiatives addressing very different agricultural and climate challenges in Madagascar's Highlands, the African Sahel and Australian Wet Tropics.

\section{Climate-smart rice subsector of Madagascar}

Resilience to climate change is a critical issue facing the country of Madagascar. High levels of poverty (75\% of the population lives below poverty line), severe environmental problems, and a dense population place the island nation in a vulnerable position [55]. Agricultural productivity is low due to poor soils and land degradation. Recent political instability has hampered economic development in the country, impacting the poor and increasing food insecurity. This confluence of socioeconomic and environmental challenges has reduced the adaptive capacity of the island's inhabitants.

The agriculture, livestock, and fisheries sectors make up $95 \%$ of national food intake and $75 \%$ of foreign exchange. The rice sector is the single most important economic activity in the country. Nearly $70 \%$ of the population earns part of its living from the rice subsector. At the same time, variability of rains, cyclones and storms, and soil erosion and degradation threaten rice production. Lack of access to inputs, technical advisory services or better-adapted varieties also hinder production.

Climate variability and extreme weather events already plague the country, and are expected to become more frequent and severe with climate change. The AlaotraMangoro subregion in the eastern part of the central highlands, the country's major rice-producing area, has been identified by the NAPA as one of the most vulnerable regions in the country and a priority for adaptation.

\section{Climate-smart practices at field and farm scale}

Approved in December 2011, 'Promoting Climate Resilience in the Rice Sector' builds upon current activities to introduce soil and water conserving practices in the AlaotraMangoro subregion, such as mulching, intercropping, cover cropping, and agroforestry, and expands upon research on integrated pest management (IPM) and system of rice intensification (SRI). The project entered the design phase in January 2012, and piloting will begin in three sites with plans to scale first to the broader region, then the entire rice producing area. Anticipated outcomes of the project also include the sustainable increase in rice yields, and an increase in on-farm employment, and income diversification, 
Table 2 Summary of case studies of climate-smart landscape initiatives

\begin{tabular}{|c|c|c|c|}
\hline & Rice subsector of Madagascar & Great Green Wall Initiative & Degree Celsius Wet Tropics Project \\
\hline Motivation & $\begin{array}{l}\text { Climate threats to rice sector } \\
\text { productivity; land degradation } \\
\text { exacerbates challenges. The } \\
\text { initiative promotes an integrated } \\
\text { approach to building resilience. }\end{array}$ & $\begin{array}{l}\text { Land degradation and drought } \\
\text { are primary threats in the region. } \\
\text { The goals of the initiative are to } \\
\text { combat desertification and poverty. }\end{array}$ & $\begin{array}{l}\text { Deforestation and heavy fertilizer } \\
\text { use contribute to land degradation } \\
\text { and cause greenhouse gas emissions. } \\
\text { There is now access to a carbon market. }\end{array}$ \\
\hline $\begin{array}{l}\text { Land use and } \\
\text { management }\end{array}$ & $\begin{array}{l}\text { Implementing and improving a } \\
\text { suite of land uses, including } \\
\text { highland forest, agroforest, } \\
\text { pasture, and lowland rice and } \\
\text { crops, to build resilience for } \\
\text { rice systems (model for } \\
\text { integrated resilient rice) }\end{array}$ & $\begin{array}{l}\text { Planned as a mosaic of land uses, to } \\
\text { manage the tradeoffs between multiple } \\
\text { uses, and integrate people's livelihood } \\
\text { objectives into the management of } \\
\text { different ecosystems }\end{array}$ & $\begin{array}{l}\text { Regional natural resource management } \\
\text { (NRM) plans include spatially-specific } \\
\text { priorities for sustainable land management, } \\
\text { and account for upstream and downstream } \\
\text { land and water interactions }\end{array}$ \\
\hline $\begin{array}{l}\text { Governance and } \\
\text { intersectoral } \\
\text { mechanisms }\end{array}$ & $\begin{array}{l}\text { Recent political instability, but } \\
\text { decentralization and building } \\
\text { local capacity are important } \\
\text { components of projects. } \\
\text { The initiative will also support } \\
\text { the creation and operation of } \\
\text { an interministerial and multi- } \\
\text { stakeholder platform on } \\
\text { resilience. }\end{array}$ & $\begin{array}{l}\text { Many levels of governance are involved, } \\
\text { from regional to local. Resource tenure is } \\
\text { weak or fragmented and is one of the } \\
\text { constraints the initiative plans to address, } \\
\text { particularly by strengthening local } \\
\text { institutions and traditional rights } \\
\text { systems, and targeting areas with } \\
\text { strong tenure. }\end{array}$ & $\begin{array}{l}\text { Decentralized decision making and strong } \\
\text { tenure systems are in place. Multiple sectors, } \\
\text { ministries, and stakeholders at various scales } \\
\text { are involved in the development and } \\
\text { implementation of the NRM plans. }\end{array}$ \\
\hline Financing of initiative & $\begin{array}{l}\text { Adaptation Fund provides funding } \\
\text { for initiative activities, which also } \\
\text { link to projects funded by } \\
\text { other organizations }\end{array}$ & $\begin{array}{l}\text { Global Environment Facility (GEF) funds } \\
\text { specific focal areas. The Least-Developed } \\
\text { Country Fund (LDCF) and Special Climate } \\
\text { Change Fund (SCCF) also provide support. } \\
\text { GEF serves as coordinating entity to pool } \\
\text { resources for initiative. }\end{array}$ & $\begin{array}{l}\text { The regional NRM body receives } \\
\text { funding from government and private } \\
\text { sector actors, which then go towards } \\
\text { implementation of the activities in the } \\
\text { plans. Aggregated carbon offsets, sold } \\
\text { to carbon markets, fund mitigation } \\
\text { activities. }\end{array}$ \\
\hline Tracking change & $\begin{array}{l}\text { A set of targets and indicators } \\
\text { has been developed for the nearly } \\
14,000 \mathrm{~km}^{2} \text { covered by the three } \\
\text { project sites. No assessment } \\
\text { has begun. }\end{array}$ & $\begin{array}{l}\text { Performance indicators, such as the } \\
\text { increase in land under sustainable } \\
\text { land management (SLM), have been } \\
\text { identified, and will be aggregated at the } \\
\text { portfolio program level. No monitoring is } \\
\text { yet underway. }\end{array}$ & $\begin{array}{l}\text { Clean Development Mechanism (CDM) } \\
\text { and United Nations Framework } \\
\text { Convention on Climate Change (UNFCCC) } \\
\text { protocols are employed to account for } \\
\text { carbon sequestration and emissions } \\
\text { reduction. There is also a set of } \\
\text { performance indicators laid out } \\
\text { in the NRM plan. }\end{array}$ \\
\hline
\end{tabular}

reaching 30,000 farmers directly and indirectly impacting $125,000-150,000$ inhabitants in the region.

\section{Diversity of land uses across the landscape}

Founded on the premise that resilience in Madagascar requires integrated solutions that affect the rice sector both directly and indirectly, the project explores a suite of practices including tree selection, improved livestock and land management, and preservation of ecosystem services (including the mitigation of climate change through building carbon stocks). Land uses in the region include highland forest, agroforest, and pasture, and lowland rice and crops. The project is promoting a model for integrated resilient rice (MIRR), which includes improved varieties, fertilizer use, and soil and water management, but also planting non-rice crops and implementing alternate land uses. Tree planting in highly eroded areas will be complemented by vegetable gardening along the bank of water bodies. Exact composition of practices will depend on the specific needs of the sites and their relation to one another.

\section{Management of land use interactions at landscape scale} For a more holistic approach to management, the model is incorporating elements of environmental, watershed level, and integrated pest and water management. Deforestation and land clearing upstream, and the resulting erosion and siltation, have direct impacts on downstream crop production and ecosystem health. Taking a wider watershed approach to management will help address these interactions and build on the synergies between land uses. For example, the project anticipates transitioning current poor livestock feed, manure, and grazing management practices to a more integrated system in which livestock systems can provide fertilizer for rice, and byproducts of the crops can be used for feed or fuel.

\section{Multi-stakeholder planning}

Implemented by the United Nations Environment Programme (UNEP), the project brings together a diverse set of stakeholders. The project emerged from the National Adaptation Programs of Action (NAPA) based on consultations at the level of national government down 
to vulnerable communities. It also builds on an existing, but not yet operational, intersectoral Rice Platform. From the producer side, a 'participatory and integrated approach' will involve not only lowland paddy cultivators, but the livestock herders and uphill growers that affect the production downstream. Non-governmental organizations, producer groups, forest management associations, community-based natural resource management entities, and any ongoing projects are included in consultation and the implementation of project activities.

Partnering with research institutions, such as the International Rice Research Institute (IRRI), le Centre National de Recherche Appliquée au Développement Rural (FOFIFA), and the World Vegetable Center, will help develop and integrate improved technologies into the project. A 'two-tiered' replication strategy will first apply lessons from the pilot to the entire Alaotra-Mangoro Region, and then integrate results into a policy strategy for the entire country. Regional partners and national policy makers will enter into dialogue and reflection sessions in order to achieve this outcome. Discussions have already taken place with the Ministries of Agriculture and Environment.

\section{Supportive landscape governance and resource tenure}

Participatory management of natural resources is already prevalent in the region, and the decisions regarding distribution of resource management rights are made collectively. The project will augment this form of decentralization by building local institutional scientific and technical capacity. There is also local enforcement of no-take conservation zones. The participating farmers are primarily landowners, and the project will work within current land tenure and property regimes.

\section{Financing for integrated landscape investment}

Targeted for the developing country parties to the Kyoto Protocol, the Adaptation Fund designates funds to adaptation projects and programs. This project was approved for a budget of $\$ 5,104,925$. The Fund receives financial resources primarily from proceeds of Clean Development Mechanism (CDM) project Certified Emissions Reduction Units (CERs), in addition to donations made by governments, foundations, non-governmental organizations, private companies, and Individual. At present, the Global Environment Facility (GEF) acts as interim secretariat, and the World Bank provides trustee services. All members of the Fund's board are representatives of Parties to the Kyoto Protocol, and the majority is from developing countries.

One way in which the project is integrating funding is through its close collaboration with other efforts already underway in the region. This includes support from the
GEF, World Bank, United Nations Development Programme (UNDP), International Fund for Agricultural Development (IFAD), and other donor organizations for activities ranging from strengthening environmental institutions and developing a baseline for water management and agricultural production to building transport infrastructure and providing training for rural development. These projects, generally focused on reducing poverty, provide a foundation and resources for the adaptation project.

\section{Tracking multiple dimensions of change}

While the pilot project has only just begun implementation, a set of targets and indicators has been developed to assess progress towards meeting the objectives.

\section{Sahel and West Africa program in support of the Great Green Wall Initiative}

Officially adopted by the African Union in 2006, the Great Green Wall Initiative is a response to the combined impacts of land degradation and drought on rural livelihoods and the environment [56]. Efforts of the Initiative span from Senegal to Djibouti. Increasing demand and use of soil, water, and vegetation resources have led to severe land degradation [57]; droughts and poor planning have exacerbated the problems, resulting in loss of topsoil and depletion of water resources.

The goal of the Great Green Wall Initiative is to expand sustainable land and water management (SLWM) in targeted landscapes and climate vulnerable areas in western Africa and Sahelian countries [57]. Institutionally, the Initiative will build national and regional capacities and support enabling conditions for both global environmental protection and sustainable development.

\section{Climate-smart practices at field and farm scale}

In order to accomplish this, countries in the region are investing in sustainable land and water management technologies that will help communities adapt production systems to climate variability and change, generate incomes and livelihoods, and secure global public goods (for example, greenhouse gas mitigation, groundwater recharge, biodiversity, and so on). On a farm level, water erosion control, windbreaks, agroforestry methods, and other climate-smart practices are being applied [56]. Climate change adaptation is addressed by adjusting production practices, in addition to utilizing adapted crop varieties, vulnerability mapping, and insurance schemes. SLWM practices that enhance soil and biomass carbon stocks will also help mitigate climate change. Goals focus on improving the uptake of SLWM in targeted areas in order to increase crop yield and adaptive capacity, while reducing risks and rehabilitating land. 


\section{Diversity of land use across the landscape}

The Initiative is planned as a mosaic of land uses that contribute to landscape restoration, climate change mitigation, biodiversity conservation, and managing international waters. Because of the geographic scope, there is an array of possible SLWM interventions possible based on the local context, including buffer zones, wildlife corridors, cropping systems practicing conservation agricultural methods, community forests, and rotational grazing systems.

\section{Management of land use interactions at landscape scale} Many of the Great Green Wall activities support a landscape approach to agricultural land management. These include the large-scale restoration and enhancement of diverse carbon stocks, reducing pressures on forests by connecting to REDD activities, and establishing close links between economic sectors and protected areas to preserve biodiversity [57]. Improved land use planning, at watershed scales down to local levels, is expected to help manage tradeoffs between multiple uses within a landscape. For example, there are competing goals in rich floodplains between grazing and crops, and in woodlands between their use as fuel sources or as protected areas. The Initiative stresses integrating 'people's livelihood objectives into the management of different ecosystems within the landscape'.

The links between ecosystems (savannah, forest, wetlands, and production systems) are recognized as being critical for providing ecosystem services such as reducing erosion and protecting pollinator habitat, as well as other social elements like managing conflict over water resources. Basin, watershed, or land use plans (including production and protected lands) and country level sector national plans with SLWM and adaptation measures are expected to address those links.

\section{Multi-stakeholder planning}

From the outset of the Initiative, the cross-border interconnected nature of the challenges posed by land degradation and climatic variability was considered. It acts as an umbrella program that fosters coordination not achievable through isolated projects. By recognizing the value of a concerted effort and a more regional approach to addressing the challenges, the Initiative plans to achieve benefits beyond what smaller scale projects could accomplish on their own. Key stakeholders at various levels (from national government down to the community levels) have been identified, and capacity building and knowledge sharing for and among those groups is one of the overarching components of the initiative.

Many projects within a country are driven by NAPAs. However, overall, building improved information and knowledge dissemination systems, such as a climate and water monitoring network, will also require institutional cooperation between and within countries. Policy builds on established organizations, such as the Comité Permanent Inter-Etats de Lutte contre la Sécheresse dans le Sahel, Centre Regional de Formation et d'Application en Agrométéorologie et Hydrologie Opérationnelle (AGRHYMET), Sahel and Sahara Observatory (OSS), the Economic Community on West African States (ECOWAS), and regional policy initiatives for West Africa Water Resources and Integrated Water Resources Management. Moreover, the Initiative supports the Sustainable Land and Water Management pillar of the CAADP and is associated with the TerrAfrica program, which focuses on scaling up sustainable land management.

\section{Supportive landscape governance and resource tenure}

The Initiative operates at various scales. On global and regional levels, it is planned to reinforce frameworks already in existence, such as UN Convention to Combat Desertification (UNCCD), United Nations Framework Convention on Climate Change (UNFCCC), the Convention on Biological Diversity (CBD), New Partnership for Africa's Development (NEPAD) Environmental Action Plan (EAP), and CAADP. Nationally, it will link into National Action Plans, and address NAPAs. TerrAfrica and GEF Strategic Investment Program financing will help identify priority sustainable land management (SLM) investments at the country level. Focal SLWM practices would be decided by participatory planning approaches.

One of the constraints to be addressed by the Initiative is the fragmented, weak, or absent resource tenure policies. The project employs different design strategies that include working in areas with clear land tenure, promoting community-driven development, building capacity in land use planning and promoting natural resources rights.

\section{Financing for integrated landscape investment}

Funds come from multiple sources, and are administered through the GEF. The GEF allocates funds based on focal area; the Great Green Wall Initiative is set up as a 'multifocal' program (biodiversity conservation, international waters, land degradation, and climate change). Individual country governments ultimately decide how much will be spent on the Initiative. The LDCF and SCCF, two UNFCCC financing mechanisms operated by the GEF that support adaptation, contribute to the Initiative's resources.

\section{Tracking multiple dimensions of change}

The Great Green Wall Initiative plans to develop a comprehensive regional SLM information system for 
monitoring landscape mosaics (remote sensing, information and communication technology (ICT), databases, and so on), in addition to regional and project level monitoring and evaluation systems. Performance indicators have been identified and include increased land area devoted to sustainable land management in targeted locations; changes in vegetation cover; increased capacity of target institutions to adapt and respond to climate variability; and change in carbon accumulation rate in soil and biomass.

\section{Degree Celsius Wet Tropics Biocarbon Sequestration and Abatement Project in Australia}

Agriculture, forestry, and land use comprise 25\% of Australia's greenhouse gas emissions, but present a large-scale opportunity for mitigation [58]. In the state of Queensland, 77\% of the emissions could be reduced or offset through rural land use. In northeastern Australia, the Degree Celsius Wet Tropics Biocarbon Sequestration and Abatement project sets a precedent for carbon sequestration projects integrated into landscapescale natural resources management. This pilot for a nationwide Degree Celsius Joint Venture, tries to ensure 'landscape positive outcomes,' proper governance frameworks, distributed costs of compliance and reporting for carbon offsets, and abatement at a scale relevant for climate impacts. At the same time, the region is expected to face considerable adverse impacts from changes in temperature and rainfall related to climate change. More intense tropical cyclones, sea level rise, and related flooding could threaten coastal agriculture and other sectors and ecosystems [59]. Land degradation and declining soil fertility will exacerbate these impacts and decrease the resilience of the agricultural systems.

\section{Climate-smart practices at field and farm scale}

Small-scale crop, horticulture, dairy, pasture, and forest lands dominate Queensland's wet tropics (130,000 ha under cropping; 47,000 ha under horticulture; 65,000 ha for pasture). Cropping systems primarily consist of banana, sugar cane, and tropical fruit. In the region input use, particularly with regards to fertilizer, and destruction of tropical forest have been high, emitting greenhouse gases, threatening biodiversity, and degrading water quality.

Mitigation activities under the Degree Celsius project include improved agricultural land management practices (such as more efficient fertilizer application, better pasture management, and increased soil carbon sequestration), avoided deforestation and degradation, and reforestation activities. These mitigation activities provide cobenefits of biodiversity conservation, water quality, and agricultural production efficiency (such as through better fertilizer management) and designed to be consistent with the existing regional natural resource management (NRM) plan.

\section{Management of land use interactions at landscape scale}

The existing NRM plan includes spatially-explicit regional priorities, taking an integrated approach to ensuring natural resources health and sustainable land management. Two World Heritage Sites are located in the region, motivating nearby interest in sustainable management. There is considerable interest to reduce the nutrients, sediment, and chemical runoff from working lands upstream that threaten the health of coral reefs that support fisheries, tourism and marine biodiversity.

\section{Multi-stakeholder planning}

Australia has an established network of 56 regional natural resources management bodies already in place, which develop and carry out management plans that integrate economic, social, and environmental policies [60]. Charged with maintaining the complementary biodiversity, sustainable agriculture, water quality, and community benefits on a landscape scale, the regional body boards are steered by landholders, consult with local groups (from farmer Landcare group representatives to industry bodies), and answer to both State and Commonwealth governments. These bodies form the foundation for achieving climate mitigation and emissions reduction goals on a large scale, while still accounting for more localized biodiversity, water services, and food security. The regional bodies have endorsed the Degree Celsius model in April 2010, and the Wet Tropics regional body plays an integral role in the pilot project.

\section{Supportive landscape governance and resource tenure}

Natural resource management plans are developed by these community-based NRM bodies. A regional approach allows for the decentralization of local and subcatchment scale decisions, as well as participatory decision making. The approach is facilitated by the strong tenure systems and clearly-defined property rights upheld by law. Most of the land in the region is privately owned. States have the power to assign rights to carbon on private land. Currently in Queensland freehold and leasehold land qualify for carbon tenure.

\section{Financing for integrated landscape investment}

The regional NRM bodies receive funds from Commonwealth, State, and local governments, community members, and the private sector. These funds are then invested in activities outlined in the NRM plans, often supporting landholders to fulfill the NRM objectives. Funding from the NRM body is coupled with the revenue from carbon credits. The Degree Celsius Wet Tropics Biocarbon Sequestration and Abatement project, 
which began in 2007, adds to the NRM plan and serves as a pilot for the aggregation of carbon offsets from the agriculture, forestry, and other land use (AFOLU) sector, to be sold on the voluntary and Australian regulated markets. This aggregation addresses the high transaction costs associated with small-scale carbon sequestration and abatement projects. Credits will be available on the voluntary market, and to offsetters on the Australian regulated carbon market. Australia's Carbon Farming Initiative enables the sale of offsets derived from land use mitigation activities. The pilot project is being carried out by Terrain NRM, a non-profit funded through a range of corporate, government, and philanthropic sources, and playing a primary role in the implementation of regional NRM plans by facilitating funding and integrating efforts across sectors.

\section{Tracking multiple dimensions of change}

In order to participate in the carbon markets, stringent protocols must be followed to account for the mitigation benefits. CDM and the UNFCCC methodologies are employed to account for emissions reductions and carbon sequestration. Participating landholders establish permanent monitoring plots on their properties. Australia's National Carbon Accounting Toolbox provides additional support for emissions estimates from natural resources management activities, including afforestation and reforestation, farm forestry, assisted natural regeneration, avoided deforestation, grazing land management, and sustainable agriculture. The natural resources management plan for the region has also laid out targets for commodity-specific best management practices that are anticipated to yield adaptation benefits. An adaptive management approach to monitoring and evaluation is built into the plan, and is based on a set of performance or implementation indicators (for example, Better Management Practice adoption rates) [59].

\section{Challenges and directions forward for implementing climate-smart landscapes}

The fundamental principles of a climate-smart landscape approach are similar to those of integrated landscape management more generally. There is a potential risk that when the objectives of climate change mitigation and adaptation are included in an already long list of livelihood and ecological objectives that integrated landscapes are expected to provide, climate goals could dilute or crowd out these other landscape functions, or alternatively be marginalized. However, in reality most of the practices and strategies that provide mitigation and adaptation are similar or even identical to those practices that lead to improved livelihoods, water quality and quantity and biodiversity benefits [29]. Therefore, a climate-smart approach has the potential to bring new resources and insights to integrated landscape management. The three examples above, and the broader experience of integrated landscape initiatives, illustrate the opportunities and challenges and suggest directions forward for implementing climate-smart landscapes.

\section{Strengthen capacities for climate-smart landscape planning and implementation of climate-smart practices}

As with climate-smart agriculture initiatives generally, far more investment is needed to help farmers and other land managers identify and adapt climate-smart farming systems. Landscape platforms need to become innovation and knowledge-sharing centers, and engage landscape facilitators to work closely with farmer and pastoral organizations.

Greater efforts are needed to improve productivity and commercialization of secondary crops, to support farmer seed-sharing networks to ensure availability of diverse crop varieties, and to encourage a diverse farming economy at landscape (if not always farm) level. Local government, private sector and farmer organizations need more information to improve management of natural and semi-natural habitats and perennial vegetation cover. These must generate financial and non-financial benefits that will sustain long-term support to maintain these spaces, including their use as community and regional food, feed and fuel reserves.

While scientific research has, in the last two decades, vastly improved our general understanding of ecological and socioeconomic processes and spatial interactions across landscapes, there is usually inadequate information in any specific landscape to inform stakeholder planning and negotiations or to guide investment priorities. Improved information bases will be critical to scaling up climate-smart landscape approaches. Meanwhile, pilot initiatives can be directed to areas with stronger databases, and landscape groups can institute adaptive management processes to build knowledge as they proceed.

\section{Strengthen institutions and political support for climate- smart landscape planning and implementation}

Planning for climate-smart landscapes will require time and patience to build a shared vision and the institutions necessary for joint coordination and implementation. These multi-stakeholder and cross-sectoral processes can be challenging to initiate and maintain; the concrete benefits from participation must be evident to all of the required actors. Trust must be built among stakeholders who may have felt skepticism or animosity towards each other in the past. There must be incentives for participation, commitments to cover financial and opportunity costs for stakeholder process and mechanisms that reduce transactions costs for participation. 
Large landscape initiatives require sustained political and institutional support, or at least cooperation, from local governments and sectoral agencies, to realize potential synergies and avoid wasteful duplication or conflict. Systematic comparative analysis of different institutional models is needed to inform design. Flexible governance mechanisms are needed to respond quickly to recommendations from stakeholder negotiations (for example, establishment of local by-laws), and new knowledge about climate-smart practices or landscape processes. Local flexibility in defining land, forest and water rights and responsibilities may be needed, with clearly established venues for debate and resolution of conflicts over tenure and rights among different groups in the landscape.

\section{Financing for integrated landscape investments}

The World Bank estimates that climate adaptation in agriculture in developing countries will cost US $\$ 2.5$ billion to US $\$ 2.6$ billion annually between 2010 and 2050; however, another study by the UNFCCC estimates an incremental cost of adaptation will be at least US $\$ 7$ billion per year in investment and financial flows in 2030 [15]. This same study calculated climate change mitigation investments needed in developing countries in 2030 to be US\$12.25 billion to US\$14 billion, excluding investments in soil carbon sequestration; infrastructure, measuring, monitoring, and capacity building could be an additional US $\$ 5$ billion. It is important that a significant share of the requisite funding, both public and private, be directed to integrated climate-smart landscape investments.

At this time, funds for agricultural development, food security, environment climate mitigation and climate adaptation generally come from different sources even though the activities supported by them are often inseparable on the ground. The consequences of this separation can be inefficiency and insufficient access to financing for climate-smart agricultural development. Private sector-led ecocertification initiatives, and payments to farmers for climate-related ecosystem services, are rarely coordinated with large landscape programs. To align interlinked climate and agriculture finance objectives, climate funds could be used strategically to influence the trajectory of agricultural investments and support agricultural institutions to deliver production, livelihood and ecosystem benefits. Financing windows could be opened specifically for multi-objective climatesmart agriculture projects and programs [61].

\section{Tracking multiple dimensions of change}

Some organizations have already incorporated indicators for monitoring and evaluation into their climate change adaptation work, but there is still room for expansion and integration. IFAD newly launched a large financing initiative for Adaptation for Smallholder Agriculture Program
(ASAP), with ten indicators to assess adaptation, including adoption rate of best management practices and water use efficiency increases [62]. CARE International has developed a community-based adaptation (CBA) framework of milestones and indicators to assess the efficacy of their program. These include indicators in categories such as livelihoods, disaster risk reduction, and local capacity development [63].

Work is ongoing to simplify and improve the efficiency of climate mitigation measurement systems for agriculture within public research institutions and among carbon project developers. However, much more research is needed to establish and develop the inexpensive and user-friendly integrated metrics that can track the full range of benefits from climate-smart landscape initiatives $[51,64]$. These integrated metrics would monitor not only carbon storage, but also the water quantity and quality, biodiversity, and other ecosystem services that are components of a climate-smart landscape and increase the adaptive capacity of the agricultural production and natural systems.

\section{Conclusions}

An integrated landscape approach in many cases will be fundamental to achieving the multiple objectives of climatesmart agriculture, namely adaptation and mitigation goals along with improvements in livelihoods, productivity and other ecosystem services. The features of a climate-smart landscape include climate-smart practices at the field and farm scale, diversity within farming systems and land uses across landscapes, and management of land use interactions to achieve synergies among a range of objectives.

Institutional mechanisms for achieving climate-smart landscapes include multi-stakeholder planning processes; supportive governance systems including resource tenure; harmonized financial mechanisms that enable the funding of initiatives with multiple, interrelated objectives; and monitoring and evaluation systems that account for a variety of impacts at a landscape scale.

Cases from Madagascar, the Sahel, Australia, and others throughout the world, demonstrate the variety of contexts in which climate-smart landscapes initiatives are already in process. While these cases illustrate a degree of success, and lessons can be drawn from them, they are still in their early stages. If properly tracked, the results can inform future investments in stakeholder capacities and institutional development to support climate-smart landscapes in all their dimensions.

Competing interests

The authors declare that they have no competing interests.

\section{Authors' contributions}

SJS and SS developed the conceptual framework for the paper and comparative analysis, based on the work program of EcoAgriculture Partners. 
RF contributed to the research and writing of the case studies and other sections of the paper. All authors read and approved the final manuscript.

\section{Acknowledgements}

The authors would like to thank the Rockefeller Foundation and the Government of the Netherlands Ministry of Economic Affairs, Agriculture and Innovation for their financial support, and Jeff Milder for his review of an earlier draft. This paper was produced as a contribution to the Global Review of the Landscapes for People, Food and Nature Initiative (www.landscapes. ecoagriculture.org).

Received: 4 May 2012 Accepted: 6 July 2012

Published: 28 August 2012

\section{References}

1. Beddington J, Asaduzzaman M, Fernandez A, Clark M, Guillou M, Jahn M, Erda L, Mamo T, Van Bo N, Nobre CA, Scholes R, Sharma R, Wakhungu J: Achieving food security in the face of climate change: Summary for policy makers from the Commission on Sustainable Agriculture and Climate Change. Copenhagen, Denmark: CGIAR Research Program on Climate Change, Agriculture and Food Security (CCAFS); 2011.

2. Lobell DB, Schlenker W, Costa-Roberts J: Climate trends and global crop production since 1980. Science 2011, 333:616-620.

3. Nelson GC, Rosegrant MW, Palazzo A, Gray I, Ingersoll C, Robertson R, Tokgoz S, Zhu T, Sulser TB, Ringler C, Msangi S, You L: Food Security, Farming, and Climate Change to 2050: Scenarios, Results, Policy Options. Washington, DC: International Food Policy Research Institute (IFPRI); 2010.

4. Parry ML: The implications of climate change for crop yields. Global food supply and risk of hunger. SAT eJournal 2007, 4:1-44.

5. Campbell B, Mann W, Meléndez-Ortiz R, Streck C, Tennigkeit T: Agriculture and Climate Change: A Scoping Report. Washington, DC: Meridian Institute; 2011.

6. Easterling W, Aggarwal P, Batima P, Brander K, Erda L, Howden M, Kirilenko A, Morton J, Soussana JF, Schmidhuber S, Tubiello F: Food, fibre and forest products. In Climate Change 2007: Impacts, Adaptation and Vulnerability. Contribution of Working Group II to the Fourth Assessment Report of the Intergovernmental Panel on Climate Change. Edited by Parry ML, Canziani OF, Palutikof OF, van der Linden PJ, Hanson CE. Cambridge, UK: Cambridge University Press; 2007:273-313.

7. Hanjra MA, Qureshi ME: Global water crisis and future food security in an era of climate change. Food Policy 2010, 35:365-377.

8. Antle JM, Capalbo SM: Adaptation of agricultural and food systems to climate change: an economic and policy perspective. Appl Econ Perspect Policy 2010, 32:386-416.

9. Falloon P, Betts R: Climate impacts on European agriculture and water management in the context of adaptation and mitigation - the importance of an integrated approach. Sci Total Environ 2010, 408:5667-5687.

10. Peterson DL, Halofsky JE, Johnson MC: Managing and adapting to changing fire regimes in a warmer climate. Landscape Ecol Fire 2011, 213:249-267.

11. Smith P, Martino D, Cai Z, Gwary D, Janzen H, Kumar P, McCarl B, Ogle S, O'Mara F, Rice C, Scholes B, Sirotenko O: Agriculture. In Climate Change 2007: Mitigation. Contribution to Working Group III to the Fourth Assessment Report of the Intergovernmental Panel on Climate Change. Cambridge, UK: Cambridge University Press; 2007

12. Desjardins RL, Sivakumar MVK, de Kimpe C: The contribution of agriculture to the state of climate: workshop summary and recommendations. Agric For Meteorol 2007, 142:314-324.

13. Bleker H: Chair's Summary. Roadmap for Action: Chair's Summary. Presented at The Global Conference on Agriculture, Food Security and Climate Change. The Hague: Ministry of Economic Affairs, Agriculture and Innovation of the Netherlands; 2011.

14. Beddington JR, Asaduzzaman M, Clark ME, Bremauntz AF, Guillou MD, Howlett DJC, Jahn MM, Lin E, Mamo T, Negra C, Nobre CA, Scholes RJ, Van Bo N, Wakhungu J: What next for agriculture after Durban? Science 2012, 335:289-290.

15. Food and Agriculture Organization of the United Nations (FAO): "ClimateSmart" Agriculture: Policies, Practices and Financing for Food Security, Adaptation and Mitigation. Rome, Italy: FAO; 2010.
16. Bank W: Climate-Smart Agriculture: A Call to Action. Washington, DC: World Bank; 2011.

17. Moorhead A: Climate, Agriculture and Food Security: A Strategy for Change. Montpellier, France: Alliance of the CGIAR Centers; 2009.

18. Vermuelen SJ, Aggarwal PK, Ainslie A, Angelone C, Campbell BM, Challinor AJ, Hansen J, Ingram JSI, Jarvis A, Kristjanson P, Lau C, Thornton CK, Wollenberg E: Agriculture, Food Security and Climate Change: Outlook for Knowledge, Tools and Action. CCAFS Report no. 3. Copenhagen, Denmark: CGIAR-ESSP Program on Climate Change, Agriculture and Food Security (CCAFS); 2010

19. Milder JC, Majanen T, Scherr SJ: Performance and Potential of Conservation Agriculture for Climate Change Adaptation and Mitigation in Sub-Saharan Africa. Ecoagriculture Discussion Paper no. 6. Washington, DC: EcoAgriculture Partners; 2011.

20. Pye-Smith C: Farming's Climate-Smart Future: Placing Agriculture at the Heart of Climate-Change Policy. Policy Pointers. Wageningen, The Netherlands and Copenhagen, Denmark: Technical Centre for Agricultural and Rural Cooperation (CTA) and CGIAR Research Program on Climate Change, Agriculture and Food Security (CCAFS); 2011

21. Delgado JA, Groffman PM, Nearing MA, Goddard T, Reicosky D, Lal R, Kitchen NR, Rice CW, Towery D, Salon P: Conservation practices to mitigate and adapt to climate change. J Soil Water Conserv 2011, 66:118A-129A.

22. Lal R, Delgado JA, Groffman JM, Millar N, Dell C, Rotz A: Management to mitigate and adapt to climate change. J Soil Water Conserv 2011, 66:276-285.

23. Scherr SJ, Sthapit S: Mitigating Climate Change Through Food and Land Use. Worldwatch Report no. 179. Washington, DC: Worldwatch Institute; 2009.

24. Landscapes for People, Landscapes for People, Food and Nature Initiative: Landscapes for People, Food and Nature: The Vision, the Evidence, and Next Steps. Washington, DC: EcoAgriculture Partners; 2012.

25. Scherr SJ, McNeely JA: Biodiversity conservation and agricultural sustainability: towards a new paradigm of 'ecoagriculture' landscapes. Phil Trans Royal Soc Biol Sci 2008, 363:477-494

26. Landscapes for People, Food and Nature Initiative (LPFN): Action and Advocacy Strategy 2012-2014. Washington, DC: Landscapes for People, Food and Nature Initiative; 2012.

27. Shames S, Scherr SJ, Wallace C, Hatcher J, Shames S, Scherr SJ, Wallace C, Hatcher J: Integrating Agendas for Forests, Agriculture and Climate Change Mitigation: Rationale and Recommendations for Landscape Strategies, National Policy and International Climate Action. Ecoagriculture Discussion Paper no. 7. Washington, DC: EcoAgriculture Partners; 2011.

28. Branca G, McCarthy N, Lipper L, Jolejole MC: Climate-Smart Agriculture: A Synthesis of Empirical Evidence of Food Security and Mitigation Benefits from Improved Cropland Management. Mitigation of Climate Change in Agriculture Series no. 3. Rome, Italy: Food and Agriculture Organization of the United Nations (FAO); 2011.

29. Nkonya E, Place F, Pender J, Mwanjololo M, Okhimamhe A, Kato E, Crespo S, Ndjeunga J, Traore S: Climate Risk Management Through Sustainable Land Management in Sub-Saharan Africa. IFPRI Discussion Paper no. 01126. Washington, DC: International Food Policy Research Institute (IFPRI); 2011

30. TerrAfrica: Land \& Climate: The Role of Sustainable Land Management for Climate Change Adaptation and Mitigation in Sub-Saharan Africa. Washington, DC, USA and Midrand, South Africa: The World Bank and NEPAD; 2010.

31. Hobbs PR, Govaerts B: How conservation agriculture can contribute to buffering climate change. In Climate Change and Crop Production. Edited by Wallingford RM. Oxford, UK: CAB International; 2009:177-199.

32. Glover JD: Reganold: perennial grains: food security for the future. Iss SCI Technol 2010, 26:41-47.

33. Baily B: LE, Purcell R: Managing for Resilience: A Landscape Approach for Food and Livelihood Security. Ithaca, NY: Cornell University; 2012.

34. Lipper L, Dalton TJ, Anderson CL, Keleman A: Agricultural markets and the sustainable utilization of crop genetic resources. In Seed Trade in Rural Markets: Implications for Crop Diversity and Agricultural Development. Rome: FAO; 2010.

35. Jackson L, van Noordwijk M, Bengtsson J, Foster W, Lipper L, Pulleman M, Said M, Snaddon J, Vodouhe R: Biodiversity and agricultural sustainagility: from assessment to adaptive management. Curr Opin Environ Sustain 2010, 2:80-87. 
36. Ureta C, Martínez-Meyer E, Perales HR, Álvarez-Buylla ER: Projecting the effects of climate change on the distribution of maize races and their wild relatives in Mexico. Glob Chang Biol 2012, 18:1073-1082.

37. Bernazzani P, Bradley BA, Opperman JJ: Integrating climate change into habitat conservation plans under the U.S. Endangered Species Act. Environ Manag 2012, 49:1103-1114.

38. Bharucha Z, Pretty J: The roles and values of wild foods in agricultural systems. Phil Trans Royal Soc Biol Sci 2010, 365:2913-2926.

39. Lovell ST, DeSantis S, Nathan CA, Olson MB, Méndez VE, Kominami HC, Erickson DL, Morris KS, Morris WN: Integrating agroecology and landscape multifunctionality in Vermont: an evolving framework to evaluate the design of agroecosystems. Agric Syst 2011, 103:327-341.

40. Harvey C: Designing agricultural landscapes for biodiversity conservation. In Farming with Nature: The Science and Practice of Ecoagriculture. Edited by Scherr SJ, McNeely JA. Washington, DC: Island Press; 2007.

41. Ricketts TH, Regetz J, Steffan-Dewenter I, Cunningham SA, Kremen C, Bogdanski A, Gemmil-Herren B, Greenleaf SS, Klein AM, Mayfield MM, Morandin LA, Ochieng A, Viana BF: Landscape effects of crop pollination services: are there general patterns? Ecol Lett 2008, 11:499-515.

42. Millar Cl, Stephenson NL, Stephens SL: Climate change and forests of the future: managing in the face of uncertainty. Ecol App/ 2007, 17:2145-2151.

43. Scherr SJ, Buck LE, Majanen T, Milder JC, Shames S: Where do private market incentives converge with landscape restoration goals? In Investing in Trees and Landscape Restoration in Africa: What, Where, and How. Edited by Dewees P, Place F, Scherr SJ, Buss C. Washington, DC: Program on Forests (PROFOR); 2011.

44. Aggarwal PK, Baethegan WE, Cooper P, Gomme R, Lee B, Meinke H, Rathore LS, Sivakumar MVK: Managing climatic risks to combat land degradation and enhance food security: key information needs. Proc Environ Sci 2010 1:305-312.

45. Macleod CJA, Haygarth PM: Integrating water and agricultural management under climate change. Sci Total Environ 2010, 408:5619-5622.

46. Eitzinger A, Läderach P, Quiroga A, Pantoja A, Gordon J: Future Climate Scenarios for Kenya's Tea Growing Areas. Cali, Colombia: Centro Internacional de Agricultura Tropical (CIAT); 2011.

47. Comprehensive African Agriculture Development Programme (CAADP): Implications of Land and Resource Tenure on Investments in Climate-Smart Agriculture. Nairobi, Kenya: Climate-Smart Agriculture Program Design Workshop; 2011.

48. Buck LE: Unit 6. Tracking change.: Landscapes Measures Resource Center. http://treadwell.cce.cornell.edu/ecoag1a/?p=167.

49. Global Environment Facility (GEF): Updated Results-Based Management Framework for the Least Developed Countries Fund (LDCF) and the Special Climate Change Fund (SCCF) and Adaptation Monitoring and Assessment Tool. Washington, DC: GEF; 2010

50. Spearman M, McGray H: Making Adaptation Count: Concepts and Options for Monitoring and Evaluation of Climate Change Adaptation. Eschborn, Germany: Deutsche Gesellschaft für Internationale Zusammenarbeit; 2011.

51. Negra C, Wollenberg E: Lessons learned from REDD for agriculture. In Climate Change Mitigation and Agriculture. Edited by Wollenberg E, Nihart A Tapio-Biström M, Grieg-Gran M. New York, NY: Earthscan from Routelage; 2012:113-122.

52. Bank W: Climate-Smart Agriculture: Increased Productivity and Food Security, Enhanced Resilience and Reduced Carbon Emissions for Sustainable Development - Opportunities and Challenges for a Converging Agenda: Country Examples. Washington, DC: World Bank; 2011.

53. EDF Group and CGIAR Challenge Program on Water and Food (CPWF): Water, Food \& Energy Nexus. Marseille, France: High-Level Panel of the 6th World Water Forum; 2012.

54. Semroc B, Schroth G, Harvey CA, Zepeda Y, Hills T, Lubis S, Arief CW, Zerbock $\mathrm{O}$, Boltz F: Climate change mitigation in agroforestry systems: linking smallholders to forest carbon markets. In Climate Change Mitigation and Agriculture. Edited by Wollenberg E, Nihart A, Tapio-Biström M, Grieg-Gran M. New York: Earthscan from Routledge; 2012:360-369.

55. United Nations Environment Programme (UNEP): Promoting Climate Resilience in the Rice Sector Through Pilot Investments in Alaotra-Mangoro Region. Climate Change Adaptation Proposal to Adaptation Fund. Washington, DC: Adaptation Fund; 2011.

56. The International Bank for Reconstruction and Development (IBRD): Sahel and West Africa Program in Support of the Great Green Wall Initiative: to
Expand Sustainable Land and Water Management in Targeted Landscapes and Climate Vulnerable Areas. Washington, DC: World Bank; 2011.

57. World Bank: Note for Information to Council Members: Sahel and West Africa WB/GEF Program in Support of the Great Green Wall Initiative. Washington, DC, USA: Prepared for GEF 40th Council Meeting and LDCF/SCCF 10th Council Meeting; 2011.

58. van Oosterzee P, Preece N, Dale A: An Australian landscape-based approach: AFOLU mitigation for smallholders. In Climate Change Mitigation and Agriculture. Edited by Wollenberg E, Nihart A, Tapio-Biström M, Grieg-Gran M. New York: Earthscan from Routelage; 2012:193-202.

59. FNQ NRM Ltd \& Rainforest CRC: Sustaining the Wet Tropics: A Regional Plan for Natural Resource Management 2004-2008. Innisfail, Australia: FNQ NRM Ltd; 2004.

60. van Oosterzee P, Preece N, Dale A: Catching the baby: accounting for biodiversity and the ecosystem sector in emissions trading. Conserv Lett 2010, 3:83-90

61. Shames S, Scherr SJ: Blending Climate and Agriculture Finance to Support Climate-Smart Landscapes. Ecoagriculture Policy Focus no. 8. Washington, DC: EcoAgriculture Partners; 2011.

62. Grainger-Jones E: IFAD's Adaptation for Smallholder Agriculture Program "ASAP". Rome, Italy: IFAD; 2012.

63. Care International Poverty, Environment and Climate Change Network: Framework of milestones and indicators for community-based adaptation. http://www.careclimatechange.org/files/toolkit/CBA_Framework.pdf.

64. Sachs JD, Remans R, Smukler SM, Winowiecki L, Andelman SJ, Cassman KG, Castle D, DeFries R, Denning G, Fanzo J, Jackson LE, Leemans R, Lehmann J, Milder JC, Naeem S, Nziguheba G, Palm CA, Pingali PL, Reganold JP, Richter DD, Scherr SJ, Sircely J, Sullivan C, Tomich TP, Sanchez PA: Effective monitoring of agriculture: a response. J Environ Monit 2012, 14:738-742.

doi:10.1186/2048-7010-1-12

Cite this article as: Scherr et al:: From climate-smart agriculture to climate-smart landscapes. Agriculture \& Food Security 2012 1:12.

\section{Submit your next manuscript to BioMed Central and take full advantage of:}

- Convenient online submission

- Thorough peer review

- No space constraints or color figure charges

- Immediate publication on acceptance

- Inclusion in PubMed, CAS, Scopus and Google Scholar

- Research which is freely available for redistribution

Submit your manuscript at www.biomedcentral.com/submit
C) Biomed Central 